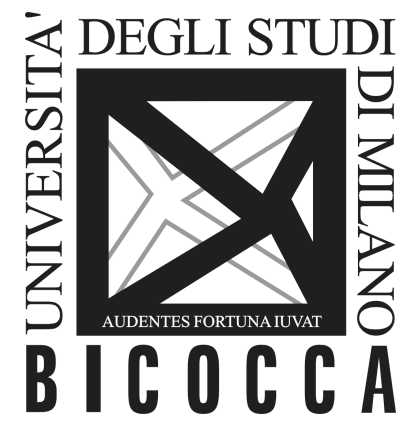

DEPARTMENT OF ECONOMICS

UNIVERSITY OF MILAN - BICOCCA

WORKING PAPER SERIES

The Welfare Impact of Land Redistribution: Evidence from a Quasi-Experimental Initiative in Malawi

Mariapia Mendola and Franklin Simtowe

No. 227 - September 2012

Dipartimento di Economia Politica

Università degli Studi di Milano - Bicocca

http://dipeco.economia.unimib.it 


\title{
The Welfare Impact of Land Redistribution: Evidence from a Quasi-Experimental Initiative in Malawi*
}

\author{
Mariapia Mendola ${ }^{\dagger}$ and Franklin Simtowe ${ }^{\ddagger}$
}

This version: September 2012

\begin{abstract}
Even though land reform may be an effective means of reducing poverty, evidence on its causal effects is scant. This paper uses household panel data combined with a quasiexperimental program to assess the impact of a joint Malawi/World Bank land redistribution project on households' productivity and well-being in southern Malawi. Double difference and matching methods are used to address sources of selection bias in identifying impacts. Results point to average positive effects of the land program on land holdings, agricultural output, income, food security and asset ownership of beneficiary households. Yet, beneficiaries do not see an improvement in access to social services such as schools and health facilities. There is also evidence of heterogeneous effects by gender and inheritance systems. Overall, our findings suggest that there is scope for reducing poverty and inequality in developing countries by implementing a decentralized, community-based, voluntary approach to land reform through the provision of land to land-poor households.
\end{abstract}

Keywords: Land Reform, Program Evaluation, Community Based Rural Land Development Program, Malawi

\footnotetext{
* The authors are grateful to the staff of the Community Based Rural Land Development Program (CBRLDP) and the World Bank office in Malawi for facilitating data collection, and for commenting on earlier versions of the paper. We also benefited from comments by participants in the 28th IAAE Conference in Brazil and the Workshop on 'Land Tenure Reforms: Impacts on Poverty and Natural Resource Management' in Norway. Financial support from the World Bank is gratefully acknowledged. Usual disclaimers apply.

${ }^{\dagger}$ Corresponding author, Department of Economics, University of Milan Bicocca, and Centro Studi L. d'Agliano (LdA), P.za dell’Ateneo Nuovo 1, 20126 Milan, Italy. E-mail: mariapia.mendola@unimib.it

₹ Alliance for a Green Revolution in Africa (AGRA), Ghana and Agricultural Policy Research Unit, University of Malawi. E-mail: $\underline{\text { fsimtowe@yahoo.com }}$
} 


\section{Introduction}

Land is a key component of wealth in many developing countries. High levels of inequality in land ownership have been shown to be detrimental for subsequent economic growth (Aghion et al., 1999; Alesina and Rodrik, 1994). Thus, land reform has been viewed by many development experts as a potential strategy for reducing poverty since land enriches the asset base of poor households and carries with it the potential for agricultural production and entrepreneurship (Besley and Burgess, 2000; de Janvry at al., 1997). Yet, while its implementation is hindered by political constraints on the one hand, on the other there is little empirical evidence on the causal effects of land redistribution on economic well-being. This paper aims at filling this gap by assessing the impact of the Community Based Rural Land Development Project (CBRLDP) in Malawi using a quasi-experimental approach.

Government statistics indicate that agriculture is the largest contributor to the Malawian economy it accounts for 38 per cent of the national Gross Domestic Product (GDP) and 80 per cent of export earnings. The sector also provides employment for 85 per cent of the population. Land allocation policies in Malawi, though, have supported the concentration of land ownership in the hands of the few large-scale estates for decades. In 2002, the Government of the Republic of Malawi adopted a new National Land Policy to correct some of the historical wrongs on land issues, and in 2005, with financial assistance from the World Bank, started implementing the CBRLDP. The latter is a decentralized and community-based land reform carried out in six pilot districts in the southern part of Malawi by employing a quasi-experimental design, i.e. involving the use of matched control and project (beneficiary) groups.

The CBRLDP initiative aims at easing land pressure and improving access to needy rural communities through voluntary land acquisition and redistribution. Its final objective is to increase the incomes of about 15,000 poor rural families through a market-based provision of land to the landless and land-poor beneficiary groups from the six Malawi districts. More specifically, the project was set up so as to provide conditional cash transfer to poor families to relocate, purchase, develop and cultivate (larger) plots of farm land.

The CBRLDP has been retained as one of the most significant interventions ever implemented to address the highly unequal land ownership patterns in postcolonial Malawi. Yet, a full impact evaluation had not been conducted. This paper provides new empirical evidence on the economic impact of the CBRLDP on land availability, agricultural productivity, input use, income and expenditure of beneficiary households. The analysis is based on a four-year panel household survey administrated to both treated and control households from 2005 through to 2009. In order to estimate the causal connection between the land project and household-level outcomes, we tackle 
both issues of selection bias and missing data for the counterfactual by using a difference-indifference estimator combined with the propensity-score matching method (Blundell and Costa Dias, 2000; Wooldridge, 2001).

Our findings show that the land redistribution project significantly increases land holdings, agricultural output and income of beneficiary households, and improves households' food security and especially durable asset ownership, while relatively decreasing access to social services such as schools and health centres. Moreover, heterogeneous treatment effects by gender and inheritance systems show that women may potentially gain more in terms of well-being and socio-economic status through targeted land policies. Overall, our evidence suggests that there is scope for reducing poverty and inequality in developing countries by implementing decentralized, market-assisted and community-based land reforms through the provision of land, joint with complementary assets such as education and health, to the landless and land-poor households.

The rest of the paper is organized as follows. Section 2 discusses the linkages between land distribution and economic well-being as explored in the existing literature. Section 3 describes the background of the CBRLDP, its components and implementation process. Section 4 presents the econometric strategy and challenges to identification. Section 5 describes the data and reports some descriptive statistics. Results from the econometric analysis and discussions on the impact of the CBRLDP are presented in Sections 6 and 7. Section 8 concludes.

\section{Background literature}

Economists have extensively investigated the linkages between (income or assets) inequality and economic growth. By theoretically formalizing the relationship either in a political economy context or in a world of missing markets, overall there seems to be little doubt that there is a strong and negative relationship between wealth inequality and subsequent economic growth (e.g. Alesina and Rodrik, 1994; Bénabou, 1996; Hoff and Lyon, 1995; Persson and Tabellini, 1995). In terms of policy, though, redistributive efforts entail significant problems either in terms of efficiency loss or social unrest. This is because marginal redistributive policies may result in lower incentives to create income or accumulate wealth, affecting both poor and non-poor people. ${ }^{1}$ On the other hand, while one-time redistribution efforts may theoretically avoid the above distortion, such policies are likely to be accompanied by large political opposition such as resistance by powerful lobbies (see also Aghion et al., 1999; Piketty, 2000).

\footnotetext{
${ }^{1}$ This point can be questioned, though, by arguing that, with incomplete markets, redistribution can alter the terms of agency problems and increase access to credit markets, thereby fostering accumulation decisions. Indeed, without ownership rights, land cannot be pledged as collateral for productivity-enhancing investments (see Bénabou, 1996; Hoff and Lyon, 1995).
} 
Thus, improved access to land is potentially a key means to alleviate poverty and help rural households to generate higher incomes (de Janvry, 1981; Binswanger et al., 1995; Finan et al. 2005). This is even more so if large proportions of the population engage in farming for subsistence needs and generating cash incomes as is the case in low-income settings in Africa. Increased access to land by the poor can contribute to the reduction of food insecurity, poverty and inequality as it enables the poor to participate in agricultural production. Most importantly, land redistribution initiatives may lead to both equity and efficiency gains if, as supported by the evidence, small farms exhibit higher productivity and these productivity gains cannot be realized by (incomplete) tenancy contracts (e.g. Binswanger et al, 1995).

However, empirical studies on the impact of land redistribution policies are relatively scant due to lack of data and reliable estimation strategies such as those employing pre- and post-reform periods. Cross-country studies provide evidence that lower inequality in the distribution of assets such as land is associated with higher subsequent growth (Birdsall and Londono, 1998; Deininger and Squire, 1998; World Bank, 2001). At a more micro level, Besley and Burgess (2000) use panel data on the 16 main Indian states from 1958 to 1992 to show that the large volume of Indian land reforms had an appreciable positive impact on growth and poverty reduction. In addition, a specific tenancy reform in the Indian state of West Bengal is shown to have led to significant increases in farm productivity (Banerjee et al., 2002). ${ }^{2}$

Overall, both theoretical and empirical contributions seem to support the idea that lower inequality in land ownership may offer an opportunity to the poor and lead to productivity gains as well as redistributive benefits. Yet, rights to land have historically been subject to challenges due to population densities in addition to the skewed relationship of the labor force to the ruling class. It is not surprising, then, that many developing countries have been smitten by enormous inequalities in land holdings, many of which currently survive.

In Malawi, the rapid expansion of estate agriculture, particularly for the production of tobacco from the 1960s to the 1980s, resulted in an unequal distribution of land (Lele, 1989; Wayne, 1988). Emphasizing the magnitude of the issue, Chirwa and Chinsinga (2008) report that while 55\% of smallholder farmers in Malawi cultivate less than one hectare, there are about 30,000 estates cultivating between 10 and 500 hectares. Furthermore, it is estimated that about $28 \%$ of the country’s cultivable arable land (about 2.6 million hectares) lies underutilized or unutilized in rural

\footnotetext{
${ }^{2}$ See also Deininger and May (2000) and Deininger et al. (2004) for a study of the impact of the agrarian reform in South Africa and Zimbabwe respectively.
} 
areas. ${ }^{3}$ The existing land inequality, coupled with the underutilization of land in large estates, has been used as a justification for land redistribution in Malawi. Acknowledging the feasibility of land redistribution in Malawi, Chirwa (2004) highlights the large scope for land redistribution on a voluntary basis in Malawi, as the country has an estimated 2.6 million hectares of suitable agricultural land that is uncultivated, and yet the landless do not have information on the availability of land and the resources that would allow them to emigrate to such areas. However, as mentioned above, there is little agreement on how land reform can be best designed and implemented. Even if the political will did exist, expropriation or land ownership ceiling initiatives entail enormous difficulties and costs of implementation. ${ }^{4}$

In Malawi, changes in the policy environment, such as the liberalization of tobacco in the 1990s, created competition for tobacco estate owners, which, coupled with declining tobacco prices, reduced the profitability of their farms and led an increasing number of estate owners to sell off their land. In 2002, a new National Land Policy was adopted by the Government of Malawi to correct some of the historical wrongs on land issues and land inequality. The favourable land policy environment, along with the availability of land for sale by willing estate owners, provided an opportunity favourable to the introduction of a land redistribution program based on voluntary land transfers between landowners (willing sellers) and the land-poor (willing buyers). The voluntary approach upon provision of conditional cash transfers entails full compensation being paid by the government (or by foreign donors) and not entirely by the beneficiaries. The latter is crucial for a successful land reform since if full compensation is paid by beneficiaries there would be no difference from a land sale which, as supported by the evidence, is hard to occur spontaneously (see Binswanger et al., 1995; Feder et al., 1998).

\section{The CBRLD Project, implementation process and its components}

Land tenure issues in Malawi are better understood by describing the historical perspectives that date as far back as the $19^{\text {th }}$ century. As expressed by Machira (2008), prior to the creation of the British protectorate of Nyasaland in 1891, European settlers, missionaries and companies started acquiring land from African chiefs ${ }^{5}$ or headmen under a "master-servant" kind of relationship.

\footnotetext{
${ }^{3}$ This is the total land that is either underutilized or unutilized as of the mid 1990s, but since there has been no recent study, this might have changed considerably in recent years.

${ }^{4}$ It can be costly in program resources and instruments of political patronage. The World Bank (2006) further reports that substantial personnel and financial resources are necessary to assess and purchase (or expropriate) land. More importantly, even if land is arguably observable, it is difficult to implement land ownership ceilings as large and powerful landowners may parcel out their holds in the names of various household members.

${ }^{5}$ Chiefs are traditional leaders. The Village Headman $(\mathrm{VH})$ is the traditional leader for the village. This man or woman inherits the position of village chief. Above the VH there is also a Group Village Headman (GVH) who is the chief for a
} 
Under the African Orders in Council 1889 and 1892, the British government appointed a commissioner who was responsible for formalizing these agreements and making new land grants in the name of the Crown. European settlers were provided with "certificates of claim”. They acquired some of the best land, most of it in the Shire Highlands located in the southern part of the country. Through this process, the Crown allocated to European settlers and companies about 15 per cent of the total land in Malawi, or 27 per cent of the total land suitable for cultivation. According to the Presidential Commission of Inquiry on Land Policy Reform (1998), this process led to the granting of about 73 per cent of the granted land to a single company, the British South Africa Company. When Malawi gained independence from Britain in 1964, the country inherited "a rural settlement structure in which some of the most fertile and well-watered lands were reserved to white farmers” (Presidential Commission of Inquiry on Land Policy Reform (PCILPR), 1998:29, cited in Holden et al., 2006).

In 1996, the Presidential Commission of Inquiry on Land Policy Reform (PCILPR) was established to undertake a broad review of land problems throughout Malawi, and recommend the main principles of a new land policy which would foster a more economically efficient, environmentally sustainable and socially equitable land tenure system. The objective of the Commission was also to recommend a national land policy that would promote equitable access to land, security of title to land, and improved land administration. The findings by the PCILPR led to the formulation of a New Land Policy which was approved by cabinet in 2002.

In 2004, with financial assistance from the International Development Association (IDA) of the World Bank, the Government of the Republic of Malawi, through the Ministry of Lands, Housing and Urban Development, started implementing a Community Based Rural Land Development Project (CBRLDP). The CBRLDP is a market-based model by which government and donor agencies provide finances and services to allow communities to buy land themselves. The Community Based Rural Land Development Project (CBRLDP) is one of the initiatives by the Government of Malawi's Land Reform Program (LRP) implemented with financial assistance in the form of a grant from the International Development Association of the World Bank. Its focus is in rural areas where poverty is most pervasive and it is also testing the community demand-driven principle for land redistribution. The Project's development objective was to increase agricultural productivity and the incomes of about 15,000 poor rural families by implementing a decentralized,

group of villages. There is yet another layer of authority for several group villages that make up a Traditional Authority (TA). Backed by the Chiefs Act of 1967, traditional leaders are responsible for, among other things, settling customary disputes, connecting residents to district assemblies, acting as gatekeepers for their subjects etc. 
community-based and voluntary approach to land reform in the six pilot districts of Mulanje, Thyolo, Machinga, Mangochi, Balaka and Ntcheu in southern Malawi.

As depicted in Figure 1, the project was pilot-tested in five districts of the southern region of Malawi, namely Machinga, Mangochi, Mulanje, Thyolo and Balaka, and in Ntcheu district in central Malawi. According to the preliminary report of the 2008 Population and Housing Census, cited in Machira (2008), the total population for Machinga, Mangochi, Mulanje and Thyolo was about 2.4 million in 2008, representing 18.4 per cent of the national population. The total population for Balaka and Ntcheu districts was 623,847. The total population in the project areas was about 3.2 million (24.5 per cent of the country's population). Based on the 2000 population statistics, Mulanje and Thyolo have one of the highest population densities in Malawi, estimated at 208 and 268 inhabitants per square kilometre, respectively (Machira, 2008). It is also reported that the two districts of Mulanje and Thyolo are, coincidentally, also the main tea-growing areas of the country. Most of the good arable land in the two districts is under tea estates, largely owned by foreign investors. Conversely, Machinga and Mangochi districts are said to have a much lower density, averaging around 97 people per square kilometre.

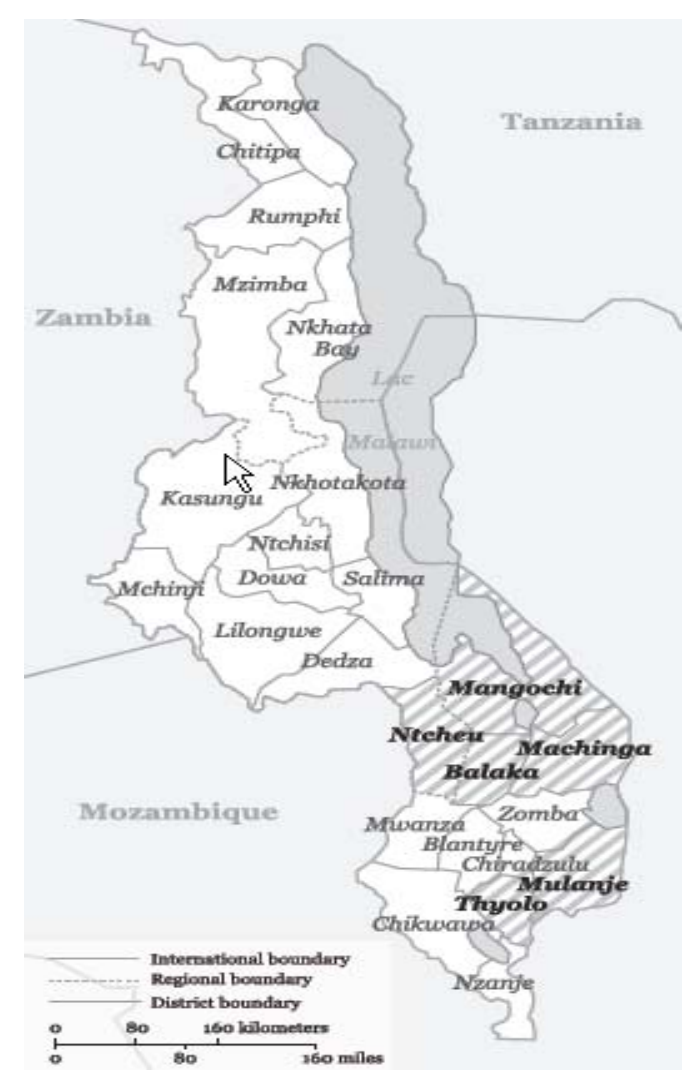

Figure 1: Pilot project districts in Malawi (Source: Machira, 2008) 
The principal outcomes of the Project were defined as:

(i). Secure community land assets;

(ii). Increased ownership of land parcels by individuals and households;

(iii). Increased chances of sustainability of both individual and group land development infrastructures;

(iv). Empowerment of the communities to manage their own development;

(v). Improved food security;

(vi). Poverty reduction;

(vii). Improved access to social amenities.

The CBRLDP is said to have drawn on the experience of Brazil, where a project based on similar core principles is being implemented on a much larger scale. Both the Brazil and the Malawi programs financed the establishment of family-scale farms. They are "market-assisted communitydriven land transfer programs” that target land-deprived, small-scale farmers. However, beneficiaries in Brazil acquire land through loans and receive grants for farm development; beneficiaries in Malawi receive grants for buying land and for farm development (Machira, 2008).

Community driven, the Project focused on rural areas and it had four components: (i) Land Acquisition and Farm Development, (ii) Land Administration, (iii) Capacity Building; and (iv) Project Management, Monitoring and Evaluation. The Project was set up so as to provide conditional cash and land transfer to poor families to relocate, purchase, develop and register new (larger) plots of farm land. Each beneficiary household received approximately 2 hectares of land, a cash grant held in a group bank account, and title to the land through a group-level title deed. The total amount per household was $\$ 1,050$, with 30 per cent that could be spent on the purchase of land, 8 per cent given as a relocation allowance prior to resettlement, and the rest of the money to be applied toward farm development. Cash was released in tranches to the beneficiary groups upon request. ${ }^{6}$ The Project ended in September 2011.

\section{Empirical strategy}

There are many important theoretical reasons why land redistribution might improve farm household well-being, but the extent to which we can be sure that the better well-being of

\footnotetext{
${ }^{6}$ Each tranche of money was released to the group as a whole, and then allocated among households. Project administrators often requested a report of how the money had been spent before releasing subsequent tranches. Beneficiaries could use the money for farm inputs, and some money for hired labor and food. It was a requirement that purchases by BGs should be based on procurement guidelines.
} 
beneficiary households compared to non-beneficiaries is due to the policy intervention is a methodological issue. Our empirical analysis aims at assessing the extent to which changes in households' welfare and behaviour are attributable to the CBRLDP through a causal relation. Ideally, randomization can correct for approximate “causal inference” by randomly assigning households or groups to treatment and control groups. In this case, we would have the information on the counterfactual situation and would be able to calculate the difference in the outcome of interest between the treated and the control group, i.e. the Average Treatment Effect (ATE) (Imbens and Angrist, 1994).

In terms of regression, we would have to estimate the following equation:

$Y_{i}=\alpha+\beta T_{i}+\gamma X_{i}+\varepsilon_{i}$

where $Y_{i}$ is the outcome variable and $T_{i}$ is the treatment dummy equal to 1 if unit $i$ is randomly treated and 0 otherwise. If $\mathrm{T}$ and $\varepsilon$ are independent (treatment is random) and under the assumption of conditional exogeneity of program placement (i.e. after controlling for observable characteristics there is no selection bias because of randomization), equation (1) can be estimated by using ordinary least squares (OLS) and the treatment effect $\beta_{\text {OLS }}$ is an unbiased estimate of the ATE or the impact of the program (Ravallion, 2008).

However, the latter will not hold anymore if we have unobserved heterogeneity in participation. This is the problem of "missing data for the counterfactual” (e.g. Blundell and Costa Dias, 2000; Wooldridge, 2001) and it is related to the general issue of "self-selection" resulting from the fact that households (partly) determine whether they receive the treatment and their decision may be related to the variables of outcome.

In order to tackle the above concern we employ both difference-in-difference (DID) and propensityscore-matching (PSM) methods.

DID estimation relies on comparison of treatment and control groups in terms of outcome changes before (baseline) and after the intervention. ${ }^{7}$ Most importantly, it allows for unobserved heterogeneity (the unobserved difference in mean counterfactual outcomes between treated and untreated units) which may lead to selection bias, by assuming that the latter is time invariant, so that the bias cancels out through differencing.

Within a regression framework, the estimating equation is specified as follows:

\footnotetext{
${ }^{7}$ That is, given a two-period setting where $\mathrm{t}=0$ before the program and $\mathrm{t}=1$ after the program implementation, letting $Y_{i}^{T}$ and $Y_{i}^{C}$ be the respective outcomes for a program beneficiary and non-treated units in time $t$, the DID method will estimate the average program impact as follows: $D I D=E\left(Y_{1}^{T}-Y_{0}^{T} \mid T_{1}=1\right)-E\left(Y_{1}^{C}-Y_{0}^{C} \mid T_{1}=0\right)$.
} 
$Y_{i}=\alpha+\beta T_{i 1} t+\rho T_{i 1}+\gamma t+\varepsilon_{i t}$.

(2)

In equation (2), the coefficient $\beta$ on the interaction between the post-program treatment variable $T_{i 1}$ and time $t$ gives the average DID effect of the program. In addition to the interaction term, the variables $T_{i 1}$ and $t$ are included separately to pick up any separate mean effects of time as well as the effect of being targeted versus not being targeted.

Yet, the DID estimator requires that the error term is uncorrelated with the other variables in the equation, that is $\operatorname{Cov}\left(\varepsilon_{i t}, T_{i 1}\right)=0 ; \operatorname{Cov}\left(\varepsilon_{i t}, t\right)=0 ; \operatorname{Cov}\left(\varepsilon_{i t}, T_{i 1} t\right)=0$. The latter, also known as the parallel-trend assumption, is critical as it means that unobserved characteristics affecting program participation do not vary over time with treatment status.

In order to tackle this issue and allow the possibility of time-variant selection bias due to initial observables, we use the predicted probability of participating in the program (the propensity score) to match the treatment units with observationally similar control units. After that, we estimate the "weighted” DID impact, where the weights are equal to 1 for treated units and to the frequency given to each matched observation for comparison units. ${ }^{8}$

PSM constructs a statistical comparison group that is based on a model of the probability of participation in the treatment, using observed characteristics. Participants are then matched on the basis of this probability, or propensity score, to non-participants. The validity of PSM depends on two conditions: (a) conditional independence (namely that, after controlling for observed characteristics, unobserved factors do not affect participation) and (b) sizable common support or overlap in propensity scores across the participants and non-participant samples. The latter condition ensures that treatment observations have comparison observations "nearby" in the propensity score distribution (Heckman et al., 1999).

Hence, we combine PSM and DID so that the average treatment effect of the program is estimated by matching units in the common support and calculating the weighted difference in the outcome variables between participants and controls before and after the intervention.

Yet, even if comparability of control and project areas could be ensured before the program through PSM upon observables, the DID approach might falter if macroeconomic changes during the program affected the two groups differently.

\footnotetext{
${ }^{8}$ Specifically, the average project impact can be written as $D I D=\left(Y_{1}^{T}-Y_{0}^{T}\right)-\sum W\left(Y_{1}^{C}-Y_{0}{ }^{C}\right)$ where $W$ is the weight given to each matching observation in making the comparison between treated and controls.
} 


\section{Data and descriptive statistics}

The empirical analysis is based on a four-round household panel data set collected among 1194 households in 6 districts (Mulanje, Thyolo, Mangochi, Machinga, Balaka and Ntcheu) in Malawi between 2006 and 2009. The data set consists of 391 beneficiary households or the "treatment group" and some "indirectly treated" households, i.e. 190 households left behind in the vacated areas and 214 households in receiving areas. The latter groups of households are partially affected by the project through changes in land availability and the labor market as a consequence of the departure or arrival of new households. Hence, we will consider these groups in the analysis of spillover effects of the program placement. Finally, the data set contains information on 397 households in similar areas of neighbouring districts of Chiradzulu and Balaka, which consists of a totally unaffected "control group”.

Although baseline data collection was conducted right after households' relocation in 2007, a number of variables are retrospective and can therefore be interpreted as "true" baseline values (WB, 2009). These include variables related to agricultural production and livestock holdings, for which all questions refer to the previous agricultural cycle ending in June 2006 (WB, 2009). While most questions on expenditures and food security refer to the current period and are therefore unusable as baseline variables, data on the number of meals taken in the lean season (or time in the year before crops are ready to harvest, January-February) refer to years preceding relocation. Indeed, all beneficiaries moved and were surveyed between July and November of 2006, after the end of the 2006 lean season and before the start of the 2007 lean season (WB IEG p.7). Subsequent rounds followed in 2007, 2008 and 2009, tracing the implementation process and schedules of prior rounds. However, due to the fact that in some cases households were not interviewed in real time, some information was collected through the recall method. The latter feature of the data will be taken into account in the empirical analysis.

The analysis for this paper makes use primarily of the first and second round (right after the program was implemented) so as to test short-run effects. However, we also test medium-term impacts using the last two rounds of the survey data as well. Overall, availability of longitudinal data allows us to estimate the difference-in-difference between the main outcome variables for the two groups of treated and control households before and after the land policy shock. Empirically we focus on measuring the impact of the CBRLDP in Malawi on the following set of outcome variables: land holding size (either agricultural, residential or both); crop and livestock portfolio; agricultural productivity for major crops (i.e. maize and tobacco); household food security (measured as meals taken in the lean season and months of reserve food); household incomes 
(levels and main sources); household expenditure (levels and expenditure items); use of improved farm inputs such as fertilizer and seed; access to social amenities such as schools, health.

Mean values of main outcome indicators across beneficiary and non-beneficiary households for subsequent survey rounds generally moved in the expected direction over time, with a tendency to increase over the period in both project and non-project households. Figure 2, for example, reports agricultural land (or gardens) size cultivated over time by beneficiary and non-project households, showing a rather stable pattern for the latter group (below 0.8 ha, on average). On the contrary, project households' amount of land increases over time, starting from 0.57 ha in the first survey round in 2006 (against 0.69 ha of control households), reaching a peak of 1.32 ha in round four (2009). Similarly, in Figure 3 we report household agricultural income, which shows a rising trend over time for beneficiary households compared to non-project households. The key question, then, is whether there is a differential impact attributable to the land program among treated households. A key aspect, though, is whether treated and controls are statistically comparable groups.

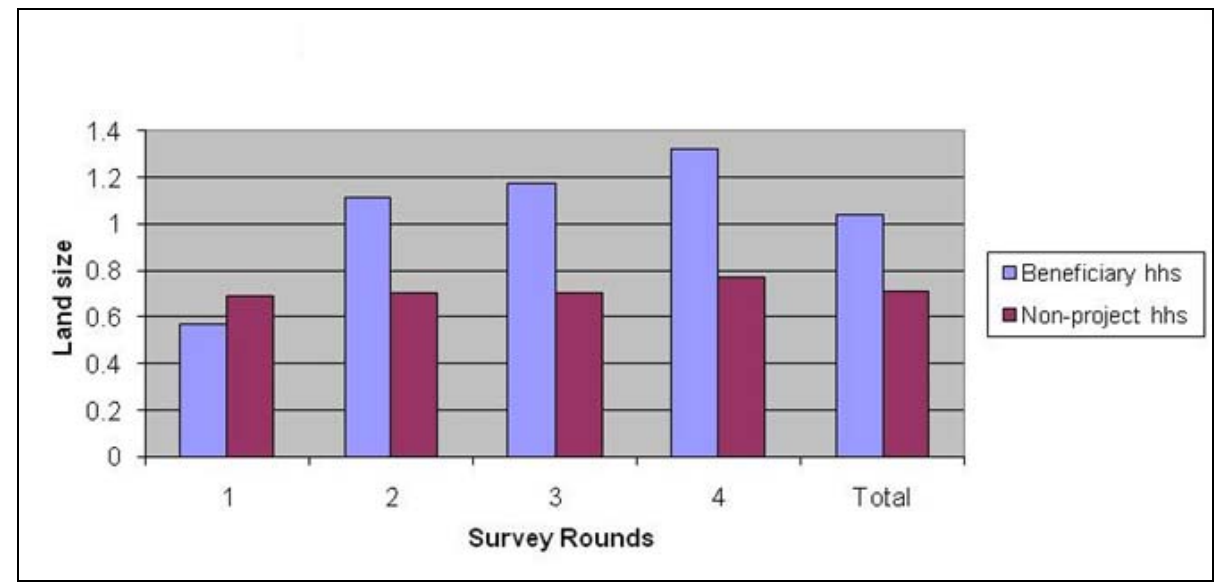

Figure 2: Agricultural land size (ha)

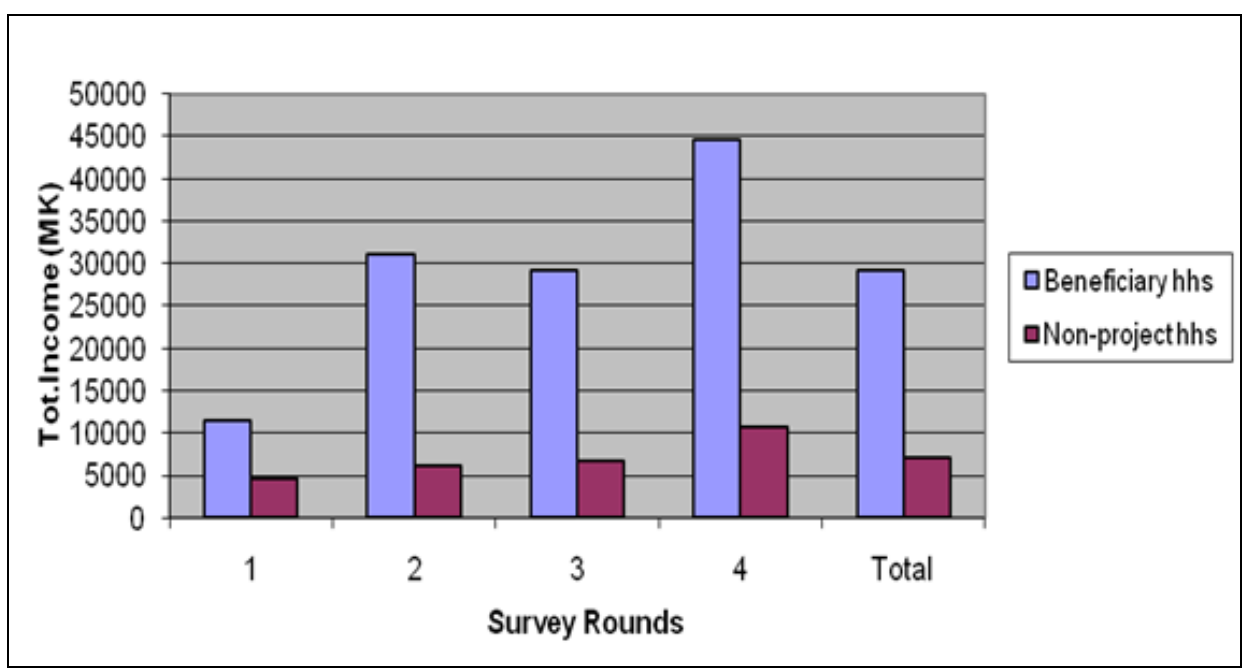

Figure 3: Yearly agricultural income (MK) 
In general, in period 1 (the baseline) non-project households located in neighbouring districts share many of the same characteristics as beneficiary households. Yet, propensity score matching technique is used to be sure that we identify a control group among the ineligible population that is similar to the beneficiaries at baseline. This is because the identifying assumption of our estimation strategy is that in the absence of the land program the household outcomes of the two groups have followed parallel paths (see also previous section). Such a condition may be implausible in the presence of significant differences in household characteristics that are possibly correlated with productivity or welfare outcomes.

In Table 2 we compare the treated and control groups of households in terms of the main observable characteristics reported in our data, such as agricultural land, household size, female-headed households, household head age, marital status, education, household assets value and average monthly income. The left columns of the table show that while some of the variables are not statistically different between the two groups, treated households have a significantly smaller household size and relatively older household head; they are also relatively worse off in terms of agricultural land, wealth status and asset ownership than the control group. This is consistent with project targeting and eligibility criteria which point to poor and landless households as key participants in the land program.

As already mentioned in the previous section, if we are willing to assume that deviation from the "parallel paths" depends solely on the differences in observable characteristics, though, conditioning on such differences does not remove all biases. This is so the selection bias is assumed to be constant over time, while we may have self-selection into treatment or, differently said, time varying factors that influence program participation. One way to adjust for time-variant difference between the two groups is to weight observations based on the propensity score of assignment, i.e. the conditional probability of belonging to each group conditional on observed covariates. The left panel of Figure 4 shows the distribution of the estimated propensity score by group. As expected, there is a larger tail of households in the control group whose estimated propensity score is close to zero, meaning they are very different (in terms of observable characteristics) from households participating in the land program. Then the weighting scheme will discount these observations, while it will attach greater importance to observations of both groups that lie in the middle range of the distribution (see right panel in Figure 4).

Finally, the right columns in Table 2 show that weighting observations according to the p-score actually eliminates difference in average group characteristics. In the next section we examine the 
key question of whether there was a differential impact attributable to the Cland program by using the combination of double differences and matching methods.

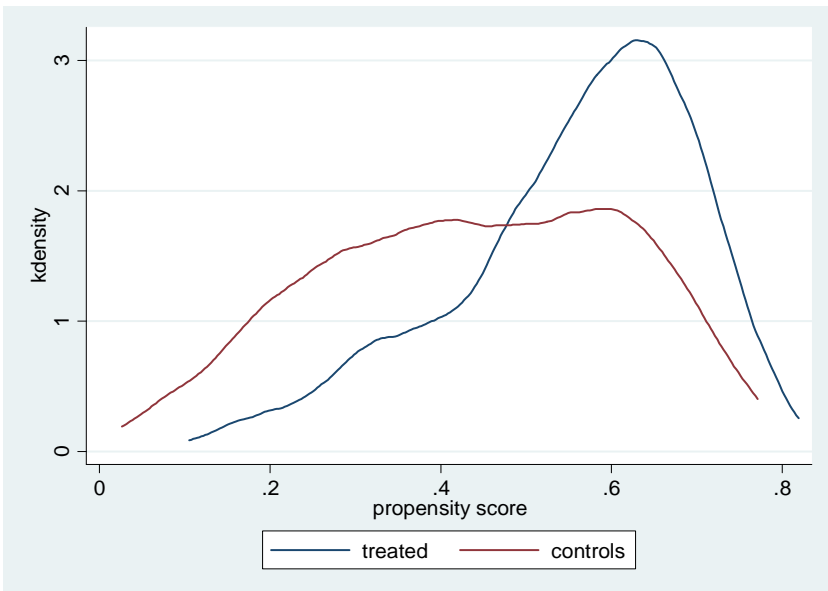

Non-weighted sample

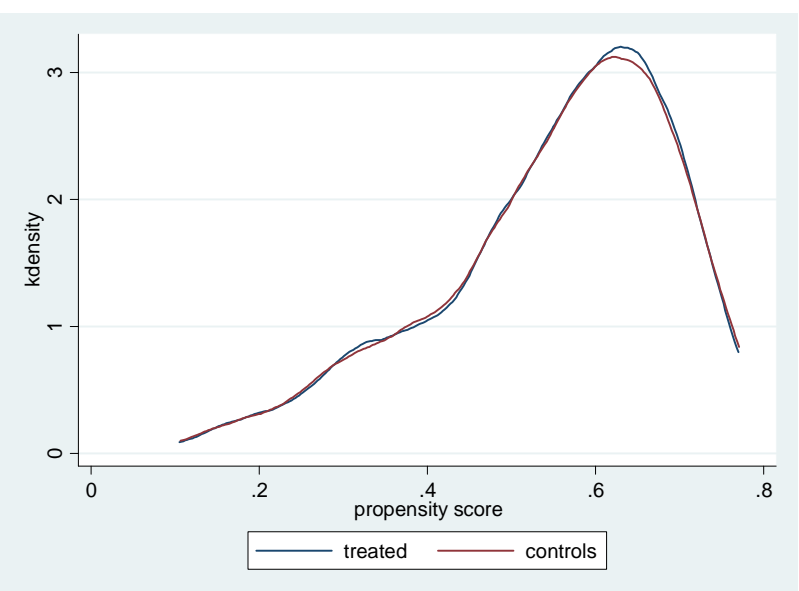

Weighted sample

Figure 4: Propensity score weighting

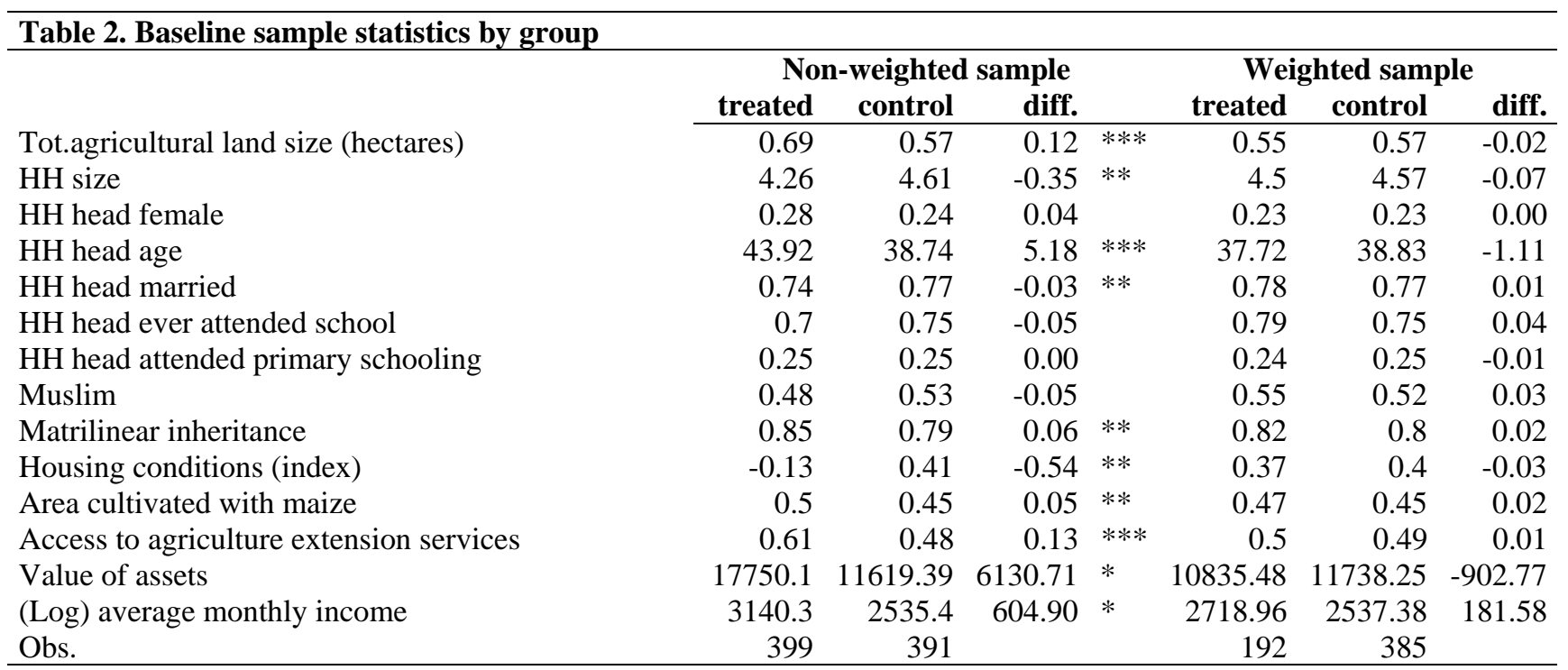

Note: This table compares the characteristics of treated and control households. The first three columns report nonweighted averages for each group, as well as the between-group difference for each variable. In the last three columns observations are weighted by the inverse propensity score matching. Standard errors are reported in parentheses. Between-group difference are: * significant at 10\%; ** significant at 5\%; *** significant at $1 \%$.

\section{Results}

As mentioned above, our evaluation methodology corrects for potential sources of selection bias by combining double difference and propensity score methods. In particular, to allow for the possibility of time variant selection bias due to initial observables, we use the predicted probability of participating in the land redistribution project (the propensity score) to match the comparison 
households in the DID estimate. PSM is implemented using a logit regression that includes initial conditions that may affect subsequent land and welfare trajectories as explanatory variables. Our impact estimates are then constructed by comparing the before and after project change in outcome measures for the beneficiary households with those for the weighted matched comparison group. We apply nearest-neighbour (NN) matching which consists of considering each treated (control) unit and searching for the control (treated) unit with the closest propensity score, i.e. the nearest neighbour. We further impose a tolerance level on the maximum propensity score distance among matched units (caliper $=0.01$ ) in order to increase the matching quality (treated that cannot find a matched control within the caliper are discarded). NN with caliper is the method that should achieve the highest reduction of the bias. However, its variance is expected to be higher than for other methods (Caliendo and Kopeinig, 2008). This is because if fewer matches can be performed, the variance of the estimates increases (because of reduced sample size). However, it is obvious that some of these matches can be fairly poor because for some treated units the nearest neighbour may have a very different propensity score and nevertheless it would contribute to the estimation of the treatment effect independently of this difference.

The key assumption of PSM-matched DID in this context is that the selection bias is conditional on the observed covariates in the baseline. The estimates will be biased if there are unobservables that affect both project placement and outcome changes. Since all project households were selected prior to the project start date based on initial observable conditions (i.e. landless, poverty) as reflected in our baseline, we should not worry about latent factors that might influence changes in both treatment and outcomes over time. Yet, in the logit model used to calculate the propensity scores we still control for an array of initial conditions that may subsequently affect changes in households' well-being. However, we can never rule out the possibility of omitted initial conditions being correlated with treatment and outcome changes over time. Results of the logit estimation of the propensity score are reported in Table 3 where we include a set of household-level characteristics observable at the baseline. The common support condition is imposed (namely the propensity score is bounded away from 0 and 1), and after considering a good set of covariates and some interaction terms the balancing property is satisfied at $1 \%$ significance level.

As shown in Table 4, treatment and matched controls do not differ significantly on any of the main household characteristics measured at baseline, with the exception of the age of the household head, whose remaining unbalance, though, is not huge (7\%) and much lower than it was before matching 
(34\%). ${ }^{9}$ Thus the p-score model we specify allows us to have almost all of the covariates well balanced (i.e. \% ASB after matching below 5\%).

Figure 5 provides a simple diagnostic on the data examined, plotting the histograms of the estimated propensity scores for treated and control groups. Here we discard six treated households for which good matches are not found (i.e. we condition on the common support). As expected, the first intervals of diagram contain most of the remaining controls but the number of comparison units in the other bins is approximately equal to the number of treated units.

\begin{tabular}{lcc}
\hline Table 3: Estimation of the p-score (logit specification) & & \\
\hline & Coeff. & S.e. \\
\cline { 2 - 3 } Total agricultural land size (hectares) & -0.25 & $(0.158)$ \\
HH head female & -0.03 & $(0.184)$ \\
HH size & $0.11^{* *}$ & $(0.045)$ \\
HH head age & 0.01 & $(0.033)$ \\
HH head age squared & -0.00 & $(0.000)$ \\
HH head attended primary school & -0.30 & $(0.557)$ \\
HH head age* primary school attendance & 0.01 & $(0.015)$ \\
Muslim & 0.24 & $(0.223)$ \\
Yao ethnic group & $-0.41^{*}$ & $(0.221)$ \\
Matrilineal inheritance & -0.32 & $(0.203)$ \\
Housing conditions (index) & $0.51^{* * *}$ & $(0.081)$ \\
Housing conditions squared (index) & $-0.11^{*}$ & $(0.055)$ \\
Value of assets & -0.00 & $(0.000)$ \\
Constant & 0.25 & $(0.732)$ \\
Observations & & 789 \\
\hline
\end{tabular}

Standard errors in parentheses. ${ }^{* * *} \mathrm{p}<0.01,{ }^{* *} \mathrm{p}<0.05,{ }^{*} \mathrm{p}<0.1$

Notes: Muslim (whose frequency is $50 \%$ in the population) is a dummy equal to 1 if the household's religion is Muslim, 0 otherwise (the latter includes Christian, which represent almost $49 \%$ of the population, and Buddhism and Traditional religions, which both represent less than $2 \%$ of the population).

9 The most frequently used indicator of the balancing is the \% Absolute Standardized Bias (ASB): $A S B=\left|\frac{\overline{X_{T}-\overline{X_{C}}}}{\sqrt{0.5\left(s_{T}^{2}+s_{C}^{2}\right)}} 100\right|$. The ASB is a measure of the average imbalance in each covariate $\mathrm{X}$ existing between treated and control units. The numerator simply calculates the difference in the average value of $\mathrm{X}$ in the treated and control group. The denominator calculates the average standard deviation in the two samples ( $\mathrm{s}^{2}$ means variance). As a rule of thumb, the balancing is considered acceptable for values of the ASB after the matching is smaller than $5 \%$. The goal with the p-score matching procedure is to achieve ASB $<5 \%$ for all the relevant confounders. Usually this is a very hard task and often we cannot succeed. The common practice is to achieve a good balancing $(\mathrm{ASB}<5 \%)$ for as many variables as possible and a high reduction in the ASB (after versus before matching) in the remaining variables. 


\begin{tabular}{|c|c|c|c|c|c|c|}
\hline \multicolumn{7}{|c|}{ Table 4: Balancing tests for beneficiaries and matched controls } \\
\hline \multirow[b]{2}{*}{ Variable } & \multirow[b]{2}{*}{ Sample } & \multicolumn{2}{|c|}{ Mean } & \multirow[b]{2}{*}{ \%bias } & \multicolumn{2}{|c|}{ t-test } \\
\hline & & Treated & Control & & t-stat & p-value \\
\hline \multirow[t]{2}{*}{ Tot.agricultural land size (hectares) } & Unmatched & 0.57 & 0.69 & -21.5 & -3.02 & 0.003 \\
\hline & Matched & 0.57 & 0.55 & 4 & 0.67 & 0.506 \\
\hline \multirow[t]{2}{*}{ HH size } & Unmatched & 4.61 & 4.27 & 17.8 & 2.51 & 0.012 \\
\hline & Matched & 4.57 & 4.50 & 3.7 & 0.53 & 0.594 \\
\hline \multirow[t]{2}{*}{ HH head female } & Unmatched & 0.24 & 0.28 & -9.4 & -1.32 & 0.188 \\
\hline & Matched & 0.23 & 0.23 & 1.2 & 0.17 & 0.864 \\
\hline \multirow{2}{*}{ HH head age } & Unmatched & 38.74 & 43.88 & -34.3 & -4.81 & 0.000 \\
\hline & Matched & 38.83 & 37.73 & 7.4 & 1.15 & 0.249 \\
\hline \multirow[t]{2}{*}{ HH head married } & Unmatched & 0.77 & 0.74 & 7.3 & 1.02 & 0.308 \\
\hline & Matched & 0.77 & 0.78 & -2.4 & -0.35 & 0.730 \\
\hline \multirow[t]{2}{*}{ HH head ever attended school } & Unmatched & 0.75 & 0.70 & 11.4 & 1.6 & 0.110 \\
\hline & Matched & 0.75 & 0.79 & -7.6 & -1.11 & 0.266 \\
\hline \multirow[t]{2}{*}{$\mathrm{HH}$ head attended primary school } & Unmatched & 0.25 & 0.25 & -0.2 & -0.02 & 0.983 \\
\hline & Matched & 0.25 & 0.24 & 3 & 0.42 & 0.676 \\
\hline \multirow[t]{2}{*}{ Muslim } & Unmatched & 0.53 & 0.47 & 10.4 & 1.46 & 0.145 \\
\hline & Matched & 0.52 & 0.55 & -4.7 & -0.65 & 0.516 \\
\hline \multirow[t]{2}{*}{ Matrilineal inheritance } & Unmatched & 0.79 & 0.85 & -15.4 & -2.17 & 0.030 \\
\hline & Matched & 0.80 & 0.82 & -4.8 & -0.64 & 0.522 \\
\hline \multirow[t]{2}{*}{ Housing conditions (index) } & Unmatched & 0.41 & -0.13 & 51.5 & 7.23 & 0.000 \\
\hline & Matched & 0.40 & 0.37 & 2.9 & 0.43 & 0.667 \\
\hline \multirow[t]{2}{*}{ Access extension services } & Unmatched & 0.48 & 0.61 & -24.7 & -3.45 & 0.001 \\
\hline & Matched & 0.49 & 0.50 & -2.1 & -0.29 & 0.772 \\
\hline \multirow[t]{2}{*}{ Value of assets } & Unmatched & 11619.00 & 17791.00 & -21.8 & -3.05 & 0.002 \\
\hline & Matched & 11738.00 & 10835.00 & 3.2 & 0.62 & 0.537 \\
\hline \multirow[t]{2}{*}{ Average monthly income } & Unmatched & 2535.40 & 3145.70 & -12.6 & -1.76 & 0.078 \\
\hline & Matched & 2537.40 & 2719.00 & -3.7 & -0.68 & 0.496 \\
\hline
\end{tabular}

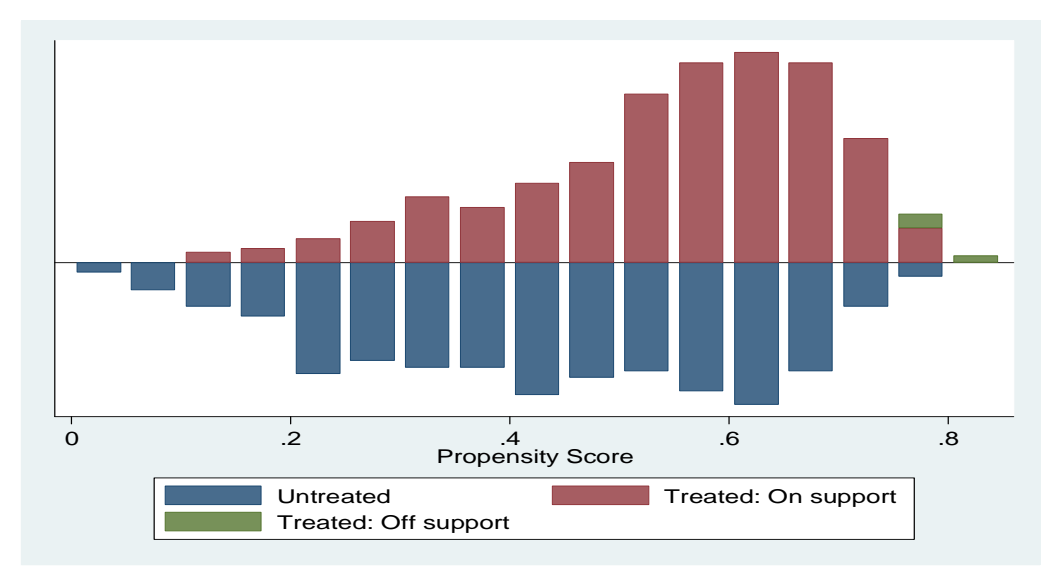

Figure 5: Estimated p-score for treated and control groups 
In what follows we report PSM-weighted DD estimates of the land project's mean impact on a set of outcome variables (introduced in Section 5) which we deem relevant to measure changes in household well-being. The analysis estimates mean impacts comparing beneficiary and nonbeneficiary households' outcomes in the baseline and for subsequent survey rounds. In particular, non-project households are used as the control group to be compared with the beneficiary one, while households in surrounding and vacated areas are excluded from the analysis. We are going to use the latter groups of households in the analysis of spillover effects as these groups are "indirectly treated" by the land program (see below). ${ }^{10}$ The estimates are given for two time periods - namely, 2006 to 2007 and 2006 to 2009, referred to as the short and medium term.

Control variables included in the regression are household size, gender, age and level of schooling of the household head, the household's religion and ethnic group, inheritance tradition and a dummy variable equal to 1 if the household was not interviewed in real time (recall variable). District fixed effects (i.e. dummies at the district level) are also included in order to control for any observable and unobservable district characteristics that may affect both the project placement and households' outcomes. Under our assumptions, PSM-DID estimates reflect causal effects of the CBRLDP.

Table 5 reports results on agricultural outcomes, namely total and agricultural land size, total maize and tobacco output and crop-specific land productivity (measured as maize and tobacco output in kilograms over land devoted to each crop respectively). We focus on maize as the major Malawian food crop and on tobacco as the country's major cash crop.

\footnotetext{
${ }^{10}$ In a robustness check, we also include households in surrounding/vacated areas in the control group, but results are not significantly affected by their inclusion.
} 
Table 5: PSM-DID estimates on agricultural outcome variables

\begin{tabular}{|c|c|c|c|c|c|c|}
\hline & $\begin{array}{c}(1) \\
\text { Land (agr \& } \\
\text { residential) }\end{array}$ & $\begin{array}{c}\text { (3) } \\
\text { Land (agr) }\end{array}$ & $\begin{array}{c}\text { (4) } \\
\text { Quantity of maize } \\
\text { (kg) }\end{array}$ & $\begin{array}{c}\text { (5) } \\
\text { Quantity of } \\
\text { tobacco (kg) }\end{array}$ & $\begin{array}{c}(6) \\
\text { Maize Land } \\
\text { productivity }\end{array}$ & $\begin{array}{c}(7) \\
\text { Tobacco Land } \\
\text { productivity }\end{array}$ \\
\hline & \multicolumn{6}{|c|}{ PANEL A: baseline vs following survey round } \\
\hline Post-program*Beneficiary & $\begin{array}{c}0.720 * * * \\
(0.082)\end{array}$ & $\begin{array}{c}0.507^{* * *} \\
(0.058)\end{array}$ & $\begin{array}{c}713.295^{* * *} \\
(81.189)\end{array}$ & $\begin{array}{c}48.961 * * * \\
(17.708)\end{array}$ & $\begin{array}{c}996.832 * * * \\
(315.611)\end{array}$ & $\begin{array}{c}106.466 * \\
(57.348)\end{array}$ \\
\hline Controls & yes & yes & yes & yes & yes & yes \\
\hline Observations & 1146 & 1146 & 1146 & 1146 & 1146 & 1146 \\
\hline R-squared & 0.33 & 0.26 & 0.23 & 0.08 & 0.04 & 0.07 \\
\hline \multirow[b]{2}{*}{ Post-program*Beneficiary } & \multicolumn{6}{|c|}{ PANEL B: baseline vs following 3 survey rounds } \\
\hline & $\begin{array}{c}0.730 * * * \\
(0.068)\end{array}$ & $\begin{array}{c}0.543^{* * *} \\
(0.048)\end{array}$ & $\begin{array}{c}361.575^{* * *} \\
(60.742)\end{array}$ & $\begin{array}{c}76.874^{* * *} \\
(14.219)\end{array}$ & $\begin{array}{c}358.734 * * \\
(174.113)\end{array}$ & $\begin{array}{c}156.620 * * * \\
(47.056)\end{array}$ \\
\hline Controls & yes & yes & yes & yes & yes & yes \\
\hline Observations & 2295 & 2295 & 2295 & 2295 & 2295 & 2295 \\
\hline R-squared & 0.36 & 0.26 & 0.17 & 0.11 & 0.03 & 0.1 \\
\hline
\end{tabular}

The project displays a significant positive impact on the ownership of both agricultural and residential land. In particular, participant households' land size rises by 0.72 ha after joining the project (0.51 ha if considering agricultural land only) and the impact is stable over time (mediumterm results shown in Panel B are not statistically different). The project impact is also positive in terms of crop-specific output and productivity as the total quantity of maize and tobacco produced by beneficiary households rises by $763 \mathrm{~kg}$ after joining the project, while their beneficiaries' cropspecific land productivity is much higher than is the case for non-project farmers. Yet, the shortterm impact of maize is higher than in the medium term, while the opposite holds for tobacco output and productivity. This may reflect some crop-specific distinctive features of production, namely tobacco is more labor-intensive than maize production in terms of both tasks and duration of work. Furthermore, tobacco requires more inputs such as seeds, fertilizer, manure, and materials for barns and bales, so it requires more working capital than maize. As a result, entry barriers to tobacco production are high and only farmers who can afford such high production costs can engage in tobacco growing (Takane, 2007).

Table 6 reports the impact of the project on the use of farm inputs and results point to a significant decrease in government coupons received by beneficiary households (only in the short run), while their use of extension services and fertilizers is not significantly affected after the project. Overall, the little or no impact of the project on agricultural input use is probably due to the little use of the initial grant available for farm operations. 


\begin{tabular}{|c|c|c|c|c|c|c|}
\hline & $\begin{array}{c}(1) \\
\text { Government } \\
\text { Coupon }\end{array}$ & $\begin{array}{c}\text { (3) } \\
\text { Extention } \\
\text { Service }\end{array}$ & $\begin{array}{c}\text { (4) } \\
\text { Fertilisers }\end{array}$ & $\begin{array}{c}\text { (5) } \\
\text { Compost }\end{array}$ & $\begin{array}{c}\text { (6) } \\
\text { Manure }\end{array}$ & $\begin{array}{c}\text { (7) } \\
\text { Pesticides }\end{array}$ \\
\hline & \multicolumn{6}{|c|}{ PANEL A: baseline vs following survey round } \\
\hline Post-program*Beneficiary & $\begin{array}{c}-0.136 * * \\
(0.066)\end{array}$ & $\begin{array}{c}0.117 \\
(0.073)\end{array}$ & $\begin{array}{c}0.086 \\
(0.060)\end{array}$ & $\begin{array}{l}-0.013 \\
(0.031)\end{array}$ & $\begin{array}{c}-0.003 \\
(0.052)\end{array}$ & $\begin{array}{c}0.005 \\
(0.035)\end{array}$ \\
\hline Controls & yes & yes & yes & yes & yes & yes \\
\hline Observations & 1146 & 1146 & 1146 & 1146 & 1146 & 1146 \\
\hline R-squared & 0.17 & 0.04 & 0.13 & 0.13 & 0.1 & 0.02 \\
\hline \multirow[b]{2}{*}{ Post-program*Beneficiary } & \multicolumn{6}{|c|}{ PANEL B: baseline vs following 3 survey rounds } \\
\hline & $\begin{array}{l}-0.067 \\
(0.054)\end{array}$ & $\begin{array}{c}0.082 \\
(0.060)\end{array}$ & $\begin{array}{l}-0.036 \\
(0.049)\end{array}$ & $\begin{array}{l}-0.036 \\
(0.026)\end{array}$ & $\begin{array}{c}0.018 \\
(0.043)\end{array}$ & $\begin{array}{c}0.029 \\
(0.028)\end{array}$ \\
\hline Controls & yes & yes & yes & yes & yes & yes \\
\hline Observations & 2295 & 2295 & 2295 & 2295 & 2295 & 2295 \\
\hline R-squared & 0.16 & 0.02 & 0.1 & 0.13 & 0.06 & 0.02 \\
\hline
\end{tabular}

In accordance with the project's positive impact in terms of agricultural output production, household food security (measured by meals taken in the lean season and months of reserve food) also proved to increase after the project. Results reported in Table 7 show that beneficiary households significantly increase the expected duration of their staple food by 3.5 months and the number of meals taken in the lean season by 0.2 after the project. This impact is slightly smaller in the medium term, but still statistically significant with respect to non-beneficiary households.

The project, though, did not improve households' access to social services as results displayed in Table 8 show. Indeed, in order to test that, we use the time needed to reach the closest school, health centre or water facility as dependent variables. PSM-DID results show that the time to reach the latter facilities increased after the project for beneficiary households compared with non-project ones. Even though results hold in the medium term as well, the dimension of the impact is modest as, for example, time to reach the closest water source on average increased by one minute. Overall, finding that access to social services (i.e. school, health centre, water supply) decreased for beneficiary households is consistent with the fact that beneficiary groups from Mulanje and Thyolo came from areas with available health and education services, and moved to more remote areas with limited access to such services (WB, 2009). 


\begin{tabular}{|c|c|c|}
\hline & $\begin{array}{c}\text { (1) } \\
\begin{array}{c}\text { Expected duration of staple food } \\
\text { (in months) }\end{array}\end{array}$ & Meals per day during lean period \\
\hline & \multicolumn{2}{|c|}{$\begin{array}{l}\text { PANEL A: baseline vs following survey round } \\
\end{array}$} \\
\hline Post-program*Beneficiary & $\begin{array}{c}3.438 * * * \\
(0.482)\end{array}$ & $\begin{array}{c}0.203 * * \\
(0.085)\end{array}$ \\
\hline Controls & yes & yes \\
\hline Observations & 1146 & 1146 \\
\hline \multirow[t]{2}{*}{ R-squared } & 0.24 & 0.09 \\
\hline & \multicolumn{2}{|c|}{ PANEL B: baseline vs following 3 survey rounds } \\
\hline Post-program*Beneficiary & $\begin{array}{c}2.403 * * * \\
(0.392)\end{array}$ & $\begin{array}{c}0.156 * * \\
(0.069)\end{array}$ \\
\hline Controls & yes & yes \\
\hline Observations & 2295 & 2295 \\
\hline R-squared & 0.14 & 0.06 \\
\hline
\end{tabular}

Table 8: PSM-DID estimates on access to social services

\begin{tabular}{|c|c|c|c|}
\hline & (1) & (3) & (4) \\
\hline & $\begin{array}{c}\text { Time to the closest } \\
\text { primary school }\end{array}$ & $\begin{array}{c}\text { Time to the closest } \\
\text { health centre }\end{array}$ & $\begin{array}{c}\text { Minutes to the closest } \\
\text { water source }\end{array}$ \\
\hline \multirow[b]{2}{*}{ Post-program*Beneficiary } & \multicolumn{3}{|c|}{ PANEL A: baseline vs following survey round } \\
\hline & $\begin{array}{c}0.293^{* * *} \\
(0.082)\end{array}$ & $\begin{array}{c}0.323 * * \\
(0.141)\end{array}$ & $\begin{array}{c}1.024 \\
(1.133)\end{array}$ \\
\hline Controls & yes & yes & yes \\
\hline Observations & 1146 & 1146 & 1146 \\
\hline R-squared & 0.3 & 0.12 & 0.06 \\
\hline \multirow[b]{2}{*}{ Post-program*Beneficiary } & \multicolumn{3}{|c|}{ PANEL B: baseline vs following 3 survey rounds } \\
\hline & $\begin{array}{l}0.126^{*} \\
(0.071)\end{array}$ & $\begin{array}{c}0.285^{* *} \\
(0.118)\end{array}$ & $\begin{array}{l}1.662 * \\
(0.947)\end{array}$ \\
\hline Controls & yes & yes & yes \\
\hline Observations & 2295 & 2295 & 2295 \\
\hline R-squared & 0.28 & 0.12 & 0.06 \\
\hline \multicolumn{4}{|c|}{$\begin{array}{l}\text { Robust standard errors in parentheses. } * \mathrm{p}<0.05, * * \mathrm{p}<0.01, * * * \mathrm{p}<0.001 \\
\text { Notes: Time to the nearest school and health center is coded in intervals, i.e. less than } 30 \text { minutes }=1 ; 31 \text { min. to } 1 \\
\text { hour=2; } 1 \mathrm{hr}+\text { to } 2 \mathrm{hrs}=3 \text {; } 2 \mathrm{hrs}+\text { to } 3 \mathrm{hrs}=4 \text {; 3hrs }+ \text { to } 4 \mathrm{hrs}=5 \text {; Half a day=6. Time di water source is measured as a } \\
\text { countinuous variable in minutes. Controls include household size, household head's gender, age and level of } \\
\text { schooling, household's religion and ethnic group, inheritance tradition, a dummy variable equal to } 1 \text { if household was } \\
\text { not interviewed in real time (recall variable) and district fixed effects. }\end{array}$} \\
\hline
\end{tabular}

Table 9 reports results on household asset ownership, revealing that the project has a positive impact on some indicators of household wealth, namely the value and number of all consumable and productive durables owned by the household, but not on livestock ownership.

Finally, we test the project's impact on household income and expenditure. Results reported in Table 10 show a positive impact on agricultural and total income of beneficiary households, which is stable over time. We also find a positive significant effect of the land project on total household 
expenditure both in the short and the medium term, but the composition of the latter is not significantly affected.

Table 9: PSM-DID estimates on asset ownership

(1)

Asset value
(3)

Total durable assets
(4)

N. of livestock

\begin{tabular}{lccc} 
Post-program*Beneficiary & $0.986^{* * *}$ & $2.230^{* * *}$ & -0.799 \\
& $(0.258)$ & $(0.653)$ & $(1.586)$ \\
& & & yes \\
Controls & yes & yes & 1146 \\
Observations & 1146 & 1146 & 0.08 \\
R-squared & 0.18 & 0.21 & PANEL B: baseline vs following 3 survey rounds \\
\hline \multicolumn{4}{c}{}
\end{tabular}

Post-program*Beneficiary
$1.120^{* * *}$

(0.199)
$2.681^{* * *}$

(0.536)

yes

Controls

Observations

R-squared

Robust standard errors in parentheses. $* \mathrm{p}<0.05, * * \mathrm{p}<0.01, * * * \mathrm{p}<0.001$

Notes: Durable goods include bycilce, radio, chairs, table, , bed, display cabinet, wheel burrow, hoe, axe, panga knife, plough, watering cane, treadle pump, sprayer, sickle, iron, boat/canoe, fishing net, clock, house. Controls include household size, household head's gender, age and level of schooling, household's religion and ethnic group, inheritance tradition, a dummy variable equal to 1 if household was not interviewed in real time (recall variable) and district fixed effects.
0.881

(1.314)

yes

2295

0.08
2295

0.19

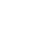


On average, our results indicate a significant improvement in the well-being of beneficiary households, especially in terms of land size, agricultural output, crop-specific agricultural productivity, food security, asset holdings and agricultural income. In general, these impacts are higher in the short term and, when they remain significant, they slightly decrease over time. Yet there is non-reassuring evidence with respect to the project impact in terms of household access to social services such as schools, health centres and water facilities, both in the short and medium term.

\subsection{Heterogeneous treatment effects with respect to gender and inheritance systems}

In this section we test whether there is any heterogeneity in the CBRLDP impact across gender of the household head. This is so as women may take up more than half of Malawi's total population, and 85 per cent of them are primarily involved in subsistence agriculture. Yet, both land concentration practices and customary land rights in Malawi largely put women at a disadvantage in terms of tenure. In particular, women who live in patrilineal communities in the northern parts of the country can only access customary land through their husbands and brothers-in-law.

Even though the CBRLDP land initiative has been implemented without any targeting of women, in our sample from the south of the country - where the matrilineal system is dominant - there is some heterogeneity in terms of the marriage or inheritance system followed by the household that we can explore. In particular, 87.7 per cent of the households follow the matrilineal rules, while 10.5 per cent pursue the patrilineal system (the remaining part follows other rules). Thus, it is of interest to see whether the novel land initiative in this area has any impact on enabling females to get access to land ownership as well as on their welfare. This would have important implications in terms of empowering women and allowing them their proper standing in the development of the country.

In Table 11 we report medium-term heterogeneous treatment effects on key outcome variables while differentiating our sample by the gender of the household head. On average, results point to a smaller impact of the land project on female-headed beneficiary households, with the exception of asset accumulation and total income to which women seem to devote more resources (Table 11, Panel A).

By differentiating even further our sample across the marriage/inheritance system followed by the household, we find that among families following the patrilineal system (Panel B), the land project effects are generally higher among male-headed beneficiary households, with the exception of total income and expenditure from which women seem to gain relatively more after the project. 
On the other hand, despite the small number of observations, in the set of households following the patrilineal system, beneficiary female household heads seem to benefit from the project relatively more than men, particularly in terms of agricultural land ownership, food security and assets value. Overall, these findings seem to suggest that there is still a large scope for improving female access to land rights and well-being through land policy. However, a thorough analysis of this heterogeneity in Malawi would require larger samples from all over the country.

\section{Spillover effects}

We now investigate whether the land redistribution project has any impact on non-participants in either vacated or surrounding areas. As mentioned above, besides beneficiary households, the data set contains information on 190 households left behind in the vacated areas and 214 households in receiving areas. These two groups of households are likely to be affected by the project through different channels such as changes in labor supply and inputs availability as a consequence of the reduced number of households in vacated areas; or increases in labor demand and supply as a consequence of the arrival of new households in surrounding areas. In particular, land redistribution may indirectly benefit vacating/surrounding households through (i) changes in food prices for net buyers; (ii) employment and wage effects in agriculture; and (iii) employment and wage effects in other sectors of economic activity through production, consumption expenditures and savings linkages with agriculture. Indirect effects via employment creation are especially important for the landless farm workers, net labor-selling smallholders and the rural non-agricultural and urban poor. $^{11}$

In order to control for these issues, in this section we measure spillover effects in both vacated and surrounding areas by restricting the sample to villages not involved in the land project. Thus, we compare neighbouring households (either in vacated or in surrounding areas) and non-beneficiary households, while excluding project participant households.

We start by reporting estimates of spillover effects in vacated areas: results displayed in Table 12 do not show important spillover effects. The only exception is tobacco land productivity in the medium term, as living in vacated areas after the project seems to lead households to produce more tobacco per unit of land than non-project households. The dismal spillover effects on productivity in vacated

\footnotetext{
${ }^{11}$ Sadoulet and de Janvry (1992) show that the relative magnitude of direct and indirect effects of technological change in agriculture on poverty can best be quantified through computable general equilibrium (CGE) models. Thus, while we check for spillover effects, the methodology we use is not able to disentangle which of the linkages between different markets is at work.
} 
villages may be the result of the migration outflows which may improve access to inputs or factors of production that can influence tobacco productivity. ${ }^{12}$

Tables 13 report estimates of spillover effects in surrounding areas receiving relocated households. Also, in this case results do not point to significant spillover effects, with the exception of food security in the long run, which seems to be lower for households living in surrounding areas than for non-project households. This may be the result of higher competition faced by surrounding households in the labor market or other livelihood resources - in particular food prices - due to the incoming of new households.

\footnotetext{
${ }^{12}$ The other immediate spillover benefit expected in vacated areas is the decrease in population density. However, this can only occur if the number of households vacating the villages is large enough compared to the remaining population. This seems not to be the case in this study, though, as vacated areas remained densely populated as a result of the relocation of just a few households. Furthermore, it is also possible that vacating households have been replaced by more households moving into the village from other areas, hence leading the population density in the vacated areas to remain the same. In other words, establishing spillover effects in vacated areas requires extra information on migration dynamics in the areas and this study did not collect such information.
} 
$\frac{\text { Table 11: Heterogenous medium-term PSM-DID estimates }}{(1)}$

\begin{tabular}{|c|c|c|c|c|c|c|c|c|c|c|c|}
\hline (4) & (5) & (6) & (7) & (8) & (9) & (10) & (11) & (12) & (13) & (14) & (15) \\
\hline $\begin{array}{l}\text { Laize Land } \\
\text { roductivity }\end{array}$ & $\begin{array}{l}\text { Tobacco Land } \\
\text { productivity }\end{array}$ & $\begin{array}{c}\text { Expected } \\
\text { duration of staple } \\
\text { food (in months) }\end{array}$ & $\begin{array}{l}\text { Meals per day } \\
\text { during lean } \\
\text { period }\end{array}$ & $\begin{array}{l}\text { Time to the } \\
\text { closest primary } \\
\text { school }\end{array}$ & $\begin{array}{l}\text { Time to the } \\
\text { closest health } \\
\text { centre }\end{array}$ & $\begin{array}{l}\text { Minutes to the } \\
\text { closest water } \\
\text { source }\end{array}$ & Asset value & $\begin{array}{l}\text { Total durable } \\
\text { assets }\end{array}$ & Total Income & $\begin{array}{l}\text { Agricultural } \\
\text { Income }\end{array}$ & $\begin{array}{c}\text { Total } \\
\text { Expenditure }\end{array}$ \\
\hline
\end{tabular}

\begin{tabular}{|c|c|c|c|c|c|c|c|c|c|c|c|c|c|c|}
\hline \multirow{3}{*}{$\begin{array}{l}\text { Post-program* } \\
\text { Beneficiary }\end{array}$} & \multicolumn{14}{|c|}{ MALE } \\
\hline & & & & & & & & & & & & & & \\
\hline & $0.776^{* * *}$ & $0.558^{* * *}$ & $416.691 * *$ & $185.283^{* * *}$ & $2.719^{* * *}$ & $0.132^{*}$ & 0.131 & $0.245^{*}$ & 0.809 & $1.063^{* * *}$ & $2.901 * * *$ & $0.517^{* *}$ & $1.238^{* *}$ & $0.341^{*}$ \\
\hline & $(0.069)$ & $(0.057)$ & (212.418) & $(58.881)$ & $(0.454)$ & $(0.078)$ & $(0.084)$ & $(0.132)$ & (1.123) & $(0.186)$ & $(0.645)$ & $(0.210)$ & $(0.521)$ & $(0.189)$ \\
\hline Observations & 1808 & 1808 & 1808 & 1808 & 1808 & 1808 & 1808 & 1808 & 1808 & 1808 & 1808 & 1808 & 1808 & 1808 \\
\hline R-squared & \multirow{2}{*}{\multicolumn{14}{|c|}{ FEMALE }} \\
\hline & & & & & & & & & & & & & & \\
\hline \multirow{3}{*}{$\begin{array}{l}\text { Post-program* } \\
\text { Beneficiary }\end{array}$} & & & & & & & & & & & & & & \\
\hline & $0.586^{* * *}$ & $0.493 * * *$ & 113.678 & 48.03 & $1.341^{*}$ & 0.199 & 0.118 & $0.430^{*}$ & $4.738^{* * *}$ & $1.311^{* *}$ & $1.927^{* *}$ & $0.837 *$ & 1.033 & 0.559 \\
\hline & $(0.166)$ & $(0.087)$ & (155.320) & (47.417) & $(0.812)$ & $(0.144)$ & $(0.121)$ & $(0.246)$ & $(1.683)$ & $(0.575)$ & $(0.879)$ & $(0.454)$ & $(1.057)$ & $(0.381)$ \\
\hline Observations & 487 & 487 & 487 & 487 & 487 & 487 & 487 & 487 & 487 & 487 & 487 & 487 & 487 & 487 \\
\hline \multirow[t]{3}{*}{ R-squared } & 0.22 & 0.23 & 0.16 & 0.11 & 0.12 & 0.09 & 0.41 & 0.13 & 0.13 & 0.23 & 0.19 & 0.07 & 0.13 & 0.03 \\
\hline & \multicolumn{14}{|c|}{ PANEL B: Matrilineal inheritance system } \\
\hline \multirow{2}{*}{\multicolumn{15}{|c|}{ Post-program* }} \\
\hline & & & & & & & & & & & & & & \\
\hline \multirow[t]{2}{*}{ Beneficiary } & $0.782^{* * *}$ & $0.598 * * *$ & 135.087 & $188.871^{* * *}$ & $2.464^{* * *}$ & 0.11 & $0.160^{*}$ & $0.365^{* *}$ & 0.604 & $1.122^{* * *}$ & $3.098 * * *$ & $0.490^{* *}$ & $1.329 * *$ & $0.341^{*}$ \\
\hline & $(0.074)$ & $(0.058)$ & (154.362) & $(54.513)$ & $(0.512)$ & $(0.087)$ & $(0.094)$ & $(0.143)$ & $(1.252)$ & $(0.205)$ & $(0.733)$ & $(0.230)$ & $(0.572)$ & $(0.207)$ \\
\hline Observations & 1621 & 1621 & 1621 & 1621 & 1621 & 1621 & 1621 & 1621 & 1621 & 1621 & 1621 & 1621 & 1621 & 1621 \\
\hline \multirow{2}{*}{ R-squared } & 0.43 & 0.28 & 0.07 & 0.1 & 0.13 & 0.05 & 0.25 & 0.13 & 0.05 & 0.14 & 0.15 & 0.05 & 0.25 & 0.05 \\
\hline & \multicolumn{14}{|c|}{ FEMALE } \\
\hline \multirow{3}{*}{$\begin{array}{l}\text { Post-program* } \\
\text { Beneficiary }\end{array}$} & & & & & & & & & & & & & & \\
\hline & $0.657^{* * *}$ & $0.502^{* * *}$ & -21.131 & 45.745 & 1.041 & 0.11 & 0.196 & 0.385 & $3.673^{* *}$ & $1.211^{* *}$ & $2.051^{* *}$ & $1.037^{*}$ & 1.804 & $0.831^{*}$ \\
\hline & $(0.161)$ & $(0.094)$ & (171.315) & (43.831) & $(0.939)$ & $(0.156)$ & $(0.135)$ & $(0.277)$ & $(1.834)$ & $(0.615)$ & $(0.886)$ & $(0.536)$ & $(1.184)$ & (0.434) \\
\hline Observations & 415 & 415 & 415 & 415 & 415 & 415 & 415 & 415 & 415 & 415 & 415 & 415 & 415 & 415 \\
\hline \multirow[t]{3}{*}{ R-squared } & 0.28 & 0.23 & 0.17 & 0.13 & 0.11 & 0.09 & 0.43 & 0.13 & 0.12 & 0.23 & 0.22 & 0.13 & 0.13 & 0.05 \\
\hline & \multicolumn{14}{|c|}{ PANEL C: Patrilineal inheritance system } \\
\hline \multirow{2}{*}{\multicolumn{15}{|c|}{ Post-program* }} \\
\hline & & & & & & & & & & & & & & \\
\hline \multirow[t]{2}{*}{ Beneficiary } & $0.606 * * *$ & 0.153 & $2383.477^{*}$ & 168.97 & $2.945 * * *$ & -0.182 & 0.00 & -0.26 & 0.978 & 0.5 & $2.641^{* *}$ & 0.296 & 0.307 & -0.173 \\
\hline & $(0.230)$ & $(0.238)$ & (1364.883) & (207.811) & $(1.010)$ & $(0.172)$ & $(0.196)$ & $(0.307)$ & (2.917) & $(0.514)$ & $(1.295)$ & $(0.616)$ & $(1.473)$ & $(0.523)$ \\
\hline Observations & 177 & 177 & 177 & 177 & 177 & 177 & 177 & 177 & 177 & 177 & 177 & 177 & 177 & 177 \\
\hline \multirow[t]{2}{*}{ R-squared } & \multirow{2}{*}{\multicolumn{14}{|c|}{ FEMALE }} \\
\hline & & & & & & & & & & & & & & \\
\hline \multicolumn{15}{|l|}{ Post-program* } \\
\hline Beneficiary & -0.085 & $1.109^{* * *}$ & 283.103 & 142.247 & $6.763^{* * *}$ & 0.298 & -0.263 & 0.381 & 4.046 & $2.290^{* *}$ & 4.395 & 0.521 & 3.017 & -1.73 \\
\hline & $(0.815)$ & $(0.345)$ & (715.144) & (165.562) & $(2.075)$ & $(0.603)$ & $(0.320)$ & $(0.519)$ & $(8.371)$ & $(1.121)$ & (2.790) & (2.109) & $(1.832)$ & (1.204) \\
\hline Observations & 45 & 45 & 45 & 45 & 45 & 45 & 45 & 45 & 45 & 45 & 45 & 45 & 45 & 45 \\
\hline R-squared & 0.62 & 0.5 & 0.27 & 0.14 & 0.43 & 0.18 & 0.51 & 0.28 & 0.19 & 0.65 & 0.26 & 0.49 & 0.49 & 0.43 \\
\hline
\end{tabular}

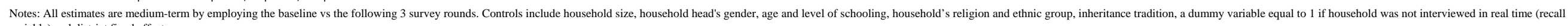
variable) and district fixed effects. 


\begin{tabular}{|c|c|c|c|c|c|c|c|c|c|c|c|c|c|c|}
\hline & (1) & (3) & (4) & (5) & (6) & (7) & (8) & (9) & $(10)$ & (11) & (12) & (13) & (14) & (15) \\
\hline & $\begin{array}{c}\text { Land (agr \& } \\
\text { residential) }\end{array}$ & Land (agr) & $\begin{array}{l}\text { Maize Land } \\
\text { productivity }\end{array}$ & $\begin{array}{l}\text { Tobacco Land } \\
\text { productivity }\end{array}$ & $\begin{array}{c}\text { Expected } \\
\text { duration of staple } \\
\text { food (in months) }\end{array}$ & $\begin{array}{l}\text { Meals per day } \\
\text { during lean } \\
\text { period }\end{array}$ & $\begin{array}{l}\text { Time to the } \\
\text { closest primary } \\
\text { school }\end{array}$ & $\begin{array}{l}\text { Time to the } \\
\text { closest health } \\
\text { centre }\end{array}$ & $\begin{array}{l}\text { Minutes to the } \\
\text { closest water } \\
\text { source }\end{array}$ & Asset value & $\begin{array}{l}\text { Total durable } \\
\text { assets }\end{array}$ & Total Income & $\begin{array}{l}\text { Agricultural } \\
\text { Income }\end{array}$ & $\begin{array}{c}\text { Total } \\
\text { Expenditure }\end{array}$ \\
\hline & \multicolumn{14}{|c|}{ PANEL A: baseline vs following survey round } \\
\hline \multirow[t]{2}{*}{$\begin{array}{l}\text { Post-program* Living in } \\
\text { vacated areas }\end{array}$} & 0.08 & 0.02 & -359.85 & 82.054 & -0.885 & 0.054 & 0.005 & 0.053 & 2.83 & 0.186 & -0.136 & 0.256 & -0.624 & 0.134 \\
\hline & $(0.119)$ & $(0.092)$ & (271.409) & $(64.015)$ & $(0.676)$ & $(0.111)$ & $(0.084)$ & $(0.177)$ & $(3.285)$ & $(0.317)$ & (1.003) & $(0.366)$ & $(0.734)$ & $(0.354)$ \\
\hline Observations & 598 & 598 & 598 & 598 & 598 & 598 & 598 & 598 & 598 & 598 & 598 & 598 & 598 & 598 \\
\hline R-squared & 0.18 & 0.15 & 0.06 & 0.12 & 0.13 & 0.09 & 0.2 & 0.13 & 0.04 & 0.32 & 0.29 & 0.08 & 0.12 & 0.06 \\
\hline & \multicolumn{14}{|c|}{ PANEL B: baseline vs following 3 survey rounds } \\
\hline \multirow{2}{*}{$\begin{array}{l}\text { Post-program* Living in } \\
\text { vacated areas }\end{array}$} & & & & & & & & & & & & & & \\
\hline & $\begin{array}{l}-0.027 \\
(0.099)\end{array}$ & $\begin{array}{c}0.016 \\
(0.080)\end{array}$ & $\begin{array}{r}-200.731 \\
(147.208)\end{array}$ & $\begin{array}{c}158.8377 * \\
(68.173)\end{array}$ & $\begin{array}{r}-0.819 \\
(0.573)\end{array}$ & $\begin{array}{c}0.09 \\
(0.094)\end{array}$ & $\begin{array}{r}-0.022 \\
(0.067)\end{array}$ & $\begin{array}{l}0.055 \\
(0.154)\end{array}$ & $\begin{array}{c}3.292 \\
(3.100)\end{array}$ & $\begin{array}{c}0.309 \\
(0.268)\end{array}$ & $\begin{array}{l}-0.566 \\
(0.755)\end{array}$ & $\begin{array}{c}0.114 \\
(0.287)\end{array}$ & $\begin{array}{r}-0.786 \\
(0.607)\end{array}$ & $\begin{array}{l}0.016 \\
(0.274)\end{array}$ \\
\hline Observations & 1197 & 1197 & 1197 & 1197 & 1197 & 1197 & 1197 & 1197 & 1197 & 1197 & 1197 & 1197 & 1197 & 1197 \\
\hline R-squared & 0.13 & 0.12 & 0.07 & 0.1 & 0.09 & 0.08 & 0.18 & 0.15 & 0.02 & 0.19 & 0.17 & 0.06 & 0.09 & 0.07 \\
\hline
\end{tabular}

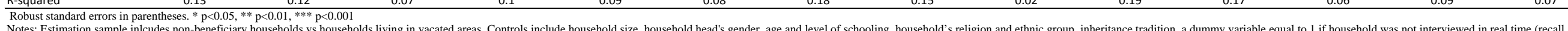

variable) and district fixed effects.

Table 13: Spillover effects- PSM-DID estimates in surrounding areas

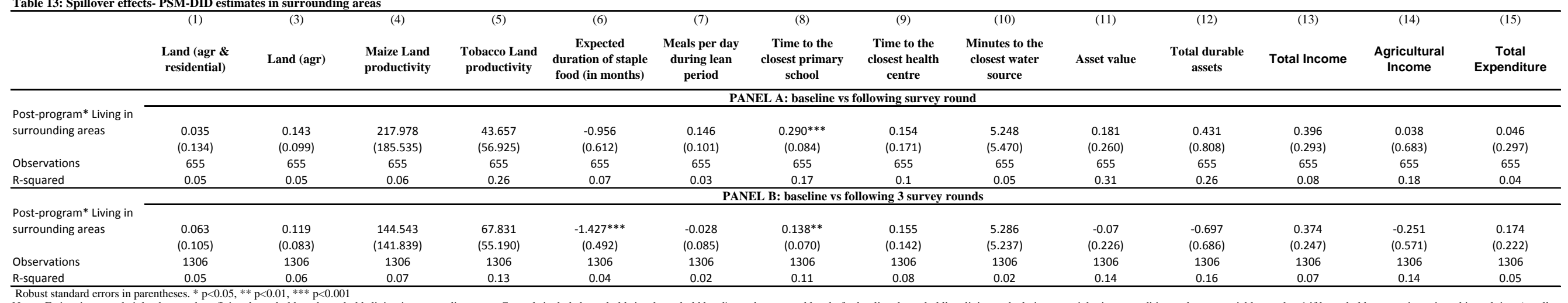

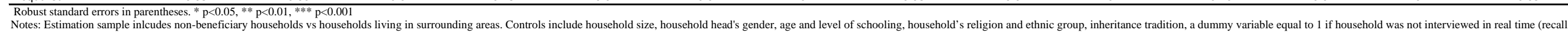
Notes: Estimation sample inlcudes 


\section{Conclusions}

Using a unique panel survey data set collected among 1194 households in 6 districts in Malawi between 2006 and 2009, this paper carries out an impact evaluation analysis of the Community Based Rural Land Development Project on the productivity and well-being of beneficiary households. The CBRLDP is a market-based land project set up by the Government of Malawi with the final aim of increasing the farmland access, and eventually income and well-being, of about 15,000 poor rural families.

We use before-and-after and treated-and-control group comparisons in order to estimate the causal connection between the land project and household-level outcomes such as land acquisition, agricultural output, productivity, food security, income and expenditure. We tackle both the selection bias problem and the problem of missing data for the counterfactual by using propensity score matching combined with difference-in-difference technique, whereby we compare how welfare outcomes of beneficiaries have changed over time compared to those of similar households who did not participate in the project.

Results show that the land redistribution project significantly increased land holdings, agricultural output and the crop-specific land productivity (i.e. maize and tobacco) of beneficiary groups in the six southern districts in Malawi. Moreover, beneficiary households significantly improved their food security, asset holding and agricultural income levels after the project. In general, these impacts are higher in the short term while they slightly decrease over time, when they remain significant. Negative or no impact on beneficiary households is found with respect to agricultural input use, household expenditure composition and access to social services such as schools, health centres and water facilities, both in the short and medium term. The latter may be due to the fact that beneficiary groups moved to new and perhaps more remote areas with limited access to reliable markets and market prices on the one hand, and social services, such as health, education and water, on the other. In particular, a lack of markets where agricultural inputs and goods can be bought may explain the adverse impact of the project on input use and household expenditure in different goods and services such as health, schooling, and parental and child care, etc. These factors combined need to be recognized as the weak part of a successful reform effort. Providing more and higherquality land to cultivate needs to be coupled with (better) access to complementary assets such as education and health as well as reliable markets, extension services and links to financial and credit institutions. This is crucial in order to make a land reform effective in boosting both agricultural productivity and household well-being. 
Heterogeneous estimates by gender and land inheritance systems show that a better targeting of female-headed households could decrease gender discrimination within region-specific customary tenure and enhance the role of women as agents of socio-economic change in society.

Significant spillover effects, instead, are not found to be a side result of the land redistribution project. Overall, the findings suggest that there is scope for reducing poverty and inequality in developing countries by implementing a decentralized, community-based, voluntary and marketassisted approach to land reform through the provision of land to the landless and land-poor households. 


\section{References}

Aghion, P., Caroli, E.and García-Peñalosa, C. (1999). "Inequality and Economic Growth: The Perspective of the New Growth Theories”, Journal of Economic Literature, 37(4): 16151660.

Alesina, A. and Rodrik, D. (1994). "Distributive Politics and Economic Growth", The Quarterly Journal of Economics, 109 (2): 465-490.

Banerjee, A., Gertler, P. and Ghatak, M. (2002). "Empowerment and Efficiency: Tenancy Reform in West Bengal”, Journal of Political Economy, 110 (2): 239-280.

Bénabou, R. (1996). "Inequality and Growth," NBER Chapters. In: NBER Macroeconomics Annual 1996, 11, 11-92 National Bureau of Economic Research, Inc.

Besley, T. and Burgess, R. (2000). "Land Reform, Poverty Reduction, and Growth: Evidence from India", The Quarterly Journal of Economics, 115(2), 389-430,

Binswanger, H., Deininger, K., Feder, G. (1995). Power, Distortions, Revolt, and Reform in Agricultural Land Relations. In: Behrman, J., Srinivasan, T.N. (Eds.), Handbook of Development Economics, vol. 3B. North-Holland, Amsterdam:

Birdsall, N. and Londono, J.L. (1998). "No Tradeoff: Efficient Growth via More Equal Human Capital in Latin America”. In: Birdsall, N., Graham, C., and Sabot, R. (Eds.), Beyond Tradeoffs: Market Reforms and Equitable Growth in Latin America, Washington, D.C.: Brookings Institution Press and Inter-American Development Bank.

Blundell, R., and Costa Dias, M. (2000). "Evaluation Methods for Non-Experimental Data". Fiscal Studies, 21(4),427468.

Caliendo, M., and S. Kopeinig (2008): "Some Practical Guidance for the Implementation of Propensity Score. Matching,” Journal of Economic Surveys, 22(1), 31-72.

Chirwa, E.W. (2008). Land Tenure, Farm Investments and Food Production in Malawi. IPPG Discussion Paper Series No. 18

Chirwa, E.W. (2008). Land Tenure, Farm Investments and Food Production in Malawi. Research Program Consortium on Improving Institutions for Pro-Poor Growth and Department for International Development (DFID). Discussion Paper Series Number 18.

Chirwa, E.W., and Chinsinga, B. (2008). The Economics and Politics of Land Reform in Malawi: A Case Study of the Community Based Rural Land Development Program. IPPG Paper Briefing No. 18

Deininger, K., and May, J. (2000). "Can there be Growth with Equity : An Initial Assessment of Land Reform in South Africa", Policy Research Working Paper Series 2451, The World Bank.

Deininger, K., and Squire, L. (1998). "New Ways of Looking at Old Issues: Inequality and Growth", Journal of Development Economics, 57(2), 259-87.

Deininger, K., Hoogeveen, H., and Kinsey, B. H. (2004). "Economic Benefits and Costs of Land Redistribution in Zimbabwe in the Early 1980s", World Development, 32(10), 1697-1709, October.

de Janvry, A. (1981). The Agrarian Question and Reformism in Latin America. Baltimore: The Johns Hopkins University Press.

de Janvry, A., Gordillo, G., and Sadoulet, E., (1997). Mexico’s Second Agrarian Reform. Center for U.S.-Mexican Studies, San Diego: University of California. 
Finan, F., Sadoulet, E., and de Janvry, A. (2005). "Measuring the Poverty Reduction Potential of Land in Rural Mexico", Journal of Development Economics, 77, 27-51.

Gayatri, D., Del Carpio, Ximena V., and Hoffmann, V. (2009). "Can a Market-Assisted Land Redistribution Program Improve the Lives of the Poor? Evidence from Malawi”, IEG Working Paper 2009/3. The World Bank.

Heckman, J., Lalonde, R., and Smith, J. (1999). “The Economics and Econometrics of Active Labor Market Programs”. In: Ashenfelter, A. and Card, D. (Ed.), in Handbook of Labor Economics, 1999, $1^{\text {st }}$ ed., vol. 3 (3), Elsevier.

Hoff, K., and Lyon, A. B. (1995). "Non-leaky Buckets: Optimal Redistributive Taxation and Agency Costs", Journal of Public Economics, 58(3), 365-390.

Imbens, G., and Angrist, J. (1994). "Identification and Estimation of Local Average Treatment Effects", Econometrica, 62(2).

Kinsey, B., Burger, K., and Gunning, J.W. (1998). "Coping with drought in Zimbabwe: Survey Evidence on Responses of Rural Households to Risk", World Development, 26(1): 89-1 10,

Lele, U. (1989) Sources of Growth in East African Agriculture, World Bank Economic Review, 3, 119-144.

Machira, S. (2008). Pilot-testing a Land Redistribution Program in Malawi. In: Binswanger, H.P, Bourguignon,C., and van den Brink, R. (Eds), Agricultural Land Redistribution: Toward Greater Consensus, The World Bank.

Persson, T., and Tabellini, G. (1992). "Growth, Distribution, and Politics", European Economic Review, 36, 593-602.

Piketty, T. (2000). "Theories of persistent inequality and intergenerational mobility". In: Atkinson, A.B., and Bourguignon, F. (Ed.), Handbook of Income Distribution, 1st ed., vol. 1, chapter 8, pages 429-476, Elsevier.

Ravallion, M. (2008). "Evaluating Anti-Poverty Programs" Handbook of Development Economics, Elsevier.

Rubin, D. B.(1978). Bayesian Inference for Causal Effects: The Role of Randomization, Annals of Statistics, 6, 3458.

Sadoulet,E., and de Janvry, A. (1992). Agricultural Trade Liberalization and Low Income Countries: A General Equilibrium-Multimarket Approach, American Journal of Agricultural Economics, 74(2), 268-80.

Takane, T. (2007). "Gambling with Liberalization: Smallholder Livelihoods in Contemporary Rural Malawi", Institute of Developing Economies Working Paper, JETRO.

Wooldridge, Jeffrey. (2001). Econometric Analysis of Cross Section and Panel Data, The MIT Press.

World Bank (2001). World Development Report 2000/2001: Attacking Poverty, New York: Oxford University Press. 